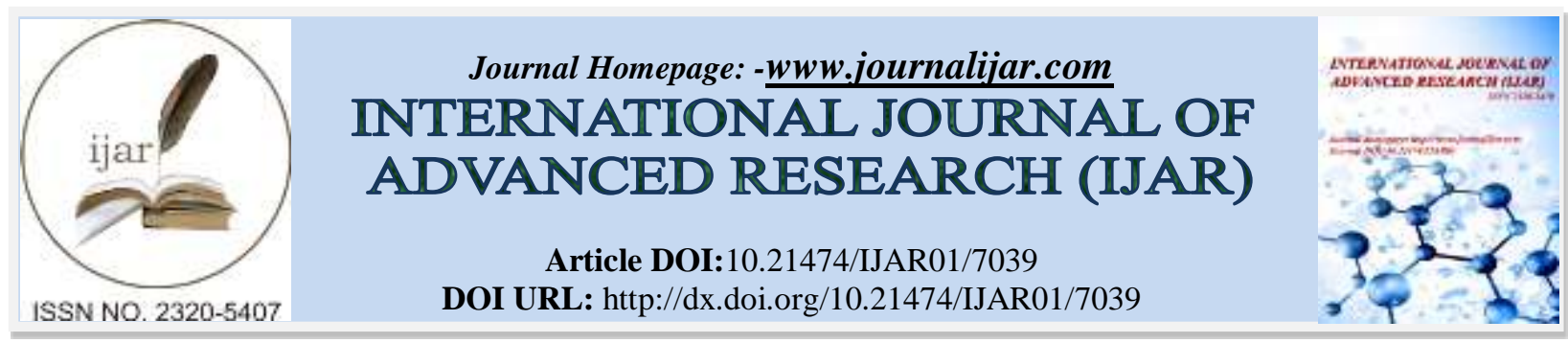

RESEARCH ARTICLE

\title{
A STUDY TO ASSESS THE EFFECTIVENESS OF PLANNED TEACHING PROGRAMME ON KNOWLEDGE REGARDING PREVENTION OF CERVICAL CANCER BY VACCINATION AMONG FEMALE FACULTY AT SELECTED UNIVERSITY ASSAM.
}

\section{Ms. Ruth Lalhmingthang ${ }^{1}$ and Ms. Rikupar Iawim ${ }^{2}$.}

1. Assistant Professor, Department of Obstetric Nursing, Sankar Madhab College of Nursing Gandhinagar, Panikhiati, Guwahati, Assam.

2. Lecturer, Department of Medical surgical Nursing,Sankar Madhab College of Nursing Gandhinagar, Panikhiati, Guwahati, Assam.

\section{Manuscript Info}

\section{Manuscript History}

Received: 05 March 2018

Final Accepted: 07 April 2018

Published: May 2018

Keywords:-

Effectiveness, Knowledge, Cervical Cancer.

\section{Abstract}

Cervical cancer is the $2^{\text {nd }}$ most common cancer of women worldwide as well in India with estimation 123,000 new cases and 67,500 deaths reported by GLOBALCON-2014 and 453.02 millions of women at risk within the age group 15 to 44 years. The objectives of the study to determine the effectiveness of planned teaching programme on regarding knowledge prevention of cervical cancer by vaccination among female faculty at selected university Assam. To identify the association between pre test knowledge and selected demographic variables

Method: Pre-experimental study was conducted among female faculty at selected university Assam. Non-probability convenience technique was used to select 40 samples. A structured questionnaire with multiple choices was used for data collection and data analysis was performed by using descriptive and inferential statistics.

Results: The results showed that the gain in knowledge score was significant at 0.05 level of significance and calculated paired ' $t$ ' value was 6 , which was more than the tabulated paired ' $t$ ' value 1.68. There was an association between the pre test knowledge and age, marital status, received HPV vaccine but no association was found with age of marriage, educational level and willingness of receiving the vaccine.

Conclusion: The findings of present study suggested that there was an effectiveness of a planned teaching programme on prevention of cervical cancer by vaccination among female faculty at selected university Assam.

Copy Right, IJAR, 2018,. All rights reserved.

\section{Introduction:-}

Cervical cancer, mainly caused by Human Papillomavirus infection, is the leading cancer in Indian women and the second most common cancer in women worldwide. Sexually transmitted human papilloma virus (HPV) infection is the most important risk factor for cervical intraepithelial neoplasia and invasive cervical cancer. The worldwide incidence of cervical cancer is approximately 510,000 new cases annually, with approximately-288,000deaths worldwide.Unlike many other cancers, cervical cancer occurs early and strikes at the productive period of a woman's 
life. The incidence rises in 30-34 years of age and peaks at 55-65 years, with a median age of 38 years (age 21-67 years). Estimates suggest that more than $80 \%$ of the sexually active women acquire genital HPV by 50 years of age. Hence, the advent of a vaccine against HPV has stirred much excitement as well as debate. HPV vaccination is for primary prevention (serotype-specific with limited cross-protection) of carcinoma cervix. A cost-effective secondgeneration HPV vaccine is needed for developing countries to address various issues specific to the region. The FDA and WHO approved two vaccine for prevention of cervical cancer. Gardasil for girls and women of the aged 9-26 and for boys at age 11 or 12 years and for those aged 13 through 21 years, if not previously vaccinated. The Cervarix for Immune compromised persons (including those with HIV infection) through age 26 years for those who did not get any or all doses when they were younger and Before sexually active.

\section{Materials and Methods:-}

In this study quantitative research approach and Pre-experimental study was conducted among female faculty at selected university Assam. Non-probability convenience technique was used to select 40 samples. A structured questionnaire with multiple choices was used for data collection and data analysis was performed by using descriptive and inferential statistics.

Table 1:-Frequency and percentage distribution of demographic variables

$n=40$

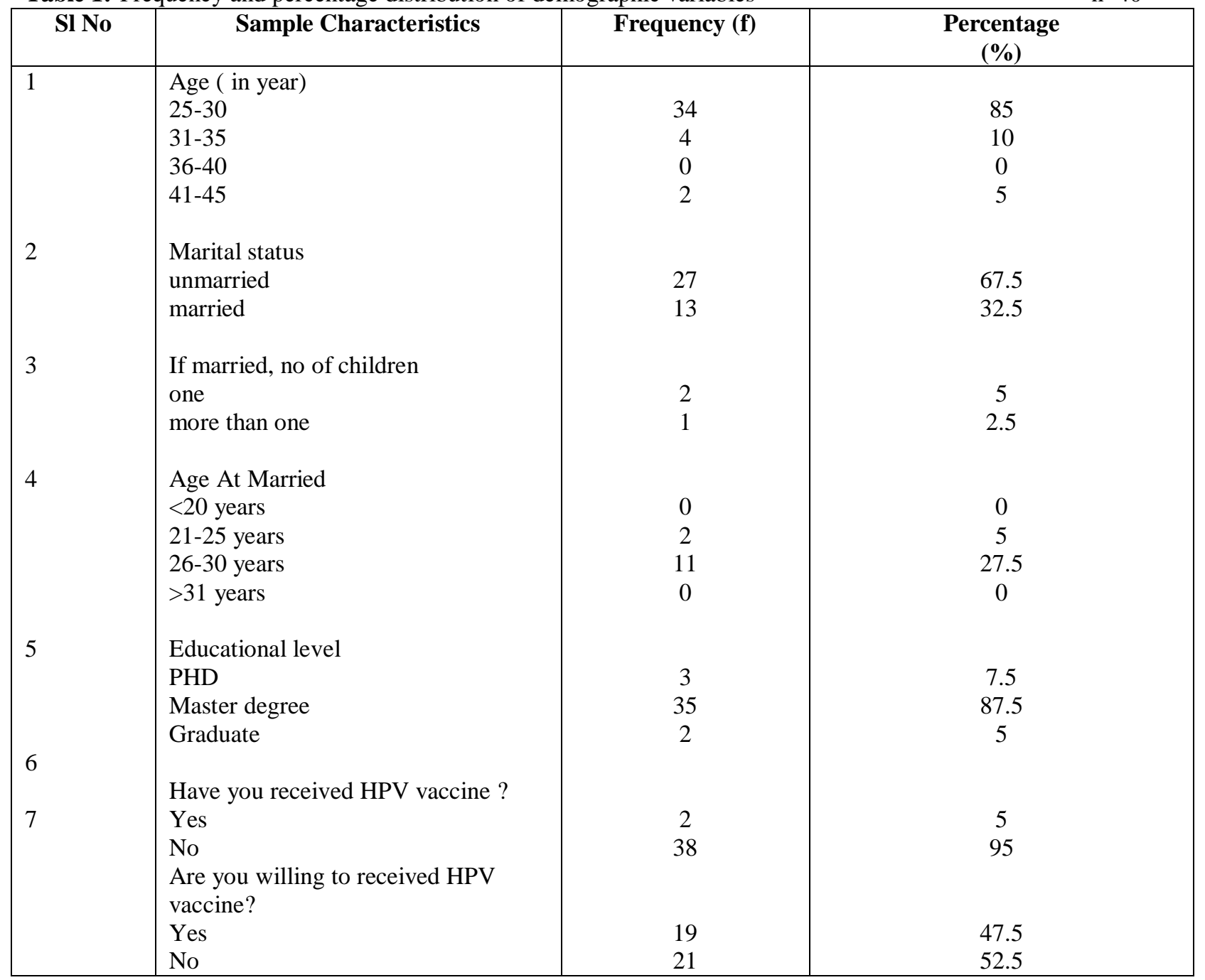


Table 2:-Pretest and Post test knowledge score $\mathbf{n}=\mathbf{4 0}$

\begin{tabular}{|c|c|c|c|}
\hline & RANGE & PRE TEST & POST TEST \\
\hline POOR & $1-15$ & 15 & 15 \\
& & $(50 \%)$ & $25(80 \%)$ \\
\hline GOOD & $16-30$ & 5 & $(16.6 \%)$ \\
\hline
\end{tabular}

Table 3:-t- test, Mean and standard deviation showing effectiveness of planned teaching programme regarding knowledge prevention of cervical cancer by vaccination. $\mathbf{n}=\mathbf{4 0}$

\begin{tabular}{|c|c|c|c|c|c|c|c|}
\hline Group & Mean & MD & SD & t-value & P-value & Df & Inference \\
\hline Pre-test scores & 14.7 & \multirow[b]{2}{*}{6.6} & 5.3 & \multirow[b]{2}{*}{6} & \multirow[b]{2}{*}{1.68} & \multirow[b]{2}{*}{39} & \multirow[b]{2}{*}{$\mathrm{S}$} \\
\hline Post- test scores & 21.3 & & 4.6 & & & & \\
\hline
\end{tabular}

$\mathrm{S}=$ Significant at $\mathbf{p}<0.05$

\section{Results:-}

The results showed that female faculty (50\%) were having good knowledge in the pre test and $83.3 \%$ were having good knowledge regarding prevention of cervical cancer by vaccination in the post test.

It also showed that the gain in knowledge score was significant at 0.05 level of significance and calculated paired' $t$ ' value was 6 , which was more than the tabulated paired 't' value 1.68.

There was an association between the pre test knowledge and age, marital status, received HPV vaccine but no association was found with age of marriage, educational level and willingness of receiving the vaccine.

\section{Conclusion:-}

The findings of present study suggested that there was an effectiveness of a planned teaching programme on prevention of cervical cancer by vaccination among female faculty at selected university Assam.

\section{References:-}

1. Schiffman, M., Castle, P. E., Jeronim, J., Rodrigue, A.C., Wacholde, S. 2007 Human papillomavirus and cervical cancer. Lancet publications, 370:890-907.

2. Ferlay, J., Soerjomataram, I., Ervik, M., Dikshit, R., Eser, S., Mathers, C., Rebelo, M., Parkin, DM., Forman, D., Bray, F., (2013).

3. GLOBOCAN 2012 v1.0, Cancer Incidence and Mortality Worldwide: IARC Cancer Base No. 11 [Internet]. Lyon, France: International Agency for Research on Cancer. Available from http://globocan.iarc.fr

4. Dutta D.C. Text Book of Gynecology. $6^{\text {th }}$ ed. Calcutta: New Central Book Agency (P) Ltd: 2004.

5. http://en.wikipedia.org/wiki/Cervical_cancer

6. http://www.medicinenet.com/cervical_cancer/page2-9.htm

7. http://www.pathguy.com/ lulo/lulo0019.htm

8. http://www.flickr.com/photos/euthman/119271 